\title{
Traumatic bile leak in war-injured Syrians: five patients treated by ERCP
}

Table 1 Details of the five war-injured Syrian civilians with bile leaks and the treatment they underwent.

\begin{tabular}{|c|c|c|c|c|c|c|}
\hline $\begin{array}{l}\text { Patient } \\
\text { number }\end{array}$ & $\begin{array}{l}\text { Age, } \\
\text { years }\end{array}$ & Sex & Liver injury & Type of bile leak & Endoscopic intervention & Short-term outcome \\
\hline 1 & 27 & Male & $\begin{array}{l}\text { Shrapnel, } \\
\text { grade } 3\end{array}$ & $\begin{array}{l}\text { High grade, common } \\
\text { hepatic duct }\end{array}$ & $\begin{array}{l}\text { Sphincterotomy with plastic } \\
\text { stent insertion }(10 \mathrm{Fr}, 12 \mathrm{~cm})\end{array}$ & $\begin{array}{l}\text { Resolution of external } \\
\text { biliary leakage }\end{array}$ \\
\hline 2 & 26 & Female & $\begin{array}{l}\text { Shrapnel, } \\
\text { grade 3-4 }\end{array}$ & Low grade, segments 6-7 & Sphincterotomy & $\begin{array}{l}\text { Resolution of external } \\
\text { biliary leakage }\end{array}$ \\
\hline 3 & 36 & Female & $\begin{array}{l}\text { Shrapnel, } \\
\text { grade } 2-3\end{array}$ & Low grade, segment 6 & Sphincterotomy & $\begin{array}{l}\text { Resolution of external } \\
\text { biliary leakage }\end{array}$ \\
\hline 4 & 12 & Male & $\begin{array}{l}\text { Crash, } \\
\text { shrapnel }\end{array}$ & $\begin{array}{l}\text { Low grade, peripheral } \\
\text { with biliopleural fistula }\end{array}$ & $\begin{array}{l}\text { Sphincterotomy with plastic } \\
\text { stent insertion }(7 \mathrm{Fr}, 7 \mathrm{~cm})\end{array}$ & $\begin{array}{l}\text { Resolution of external } \\
\text { biliary leakage }\end{array}$ \\
\hline 5 & 15 & Male & $\begin{array}{l}\text { Shrapnel, } \\
\text { grade } 3\end{array}$ & High grade, segments $5-6$ & $\begin{array}{l}\text { Sphincterotomy with plastic } \\
\text { stent insertion }(10 \mathrm{Fr}, 10 \mathrm{~cm})\end{array}$ & $\begin{array}{l}\text { Resolution of external } \\
\text { biliary leakage }\end{array}$ \\
\hline
\end{tabular}
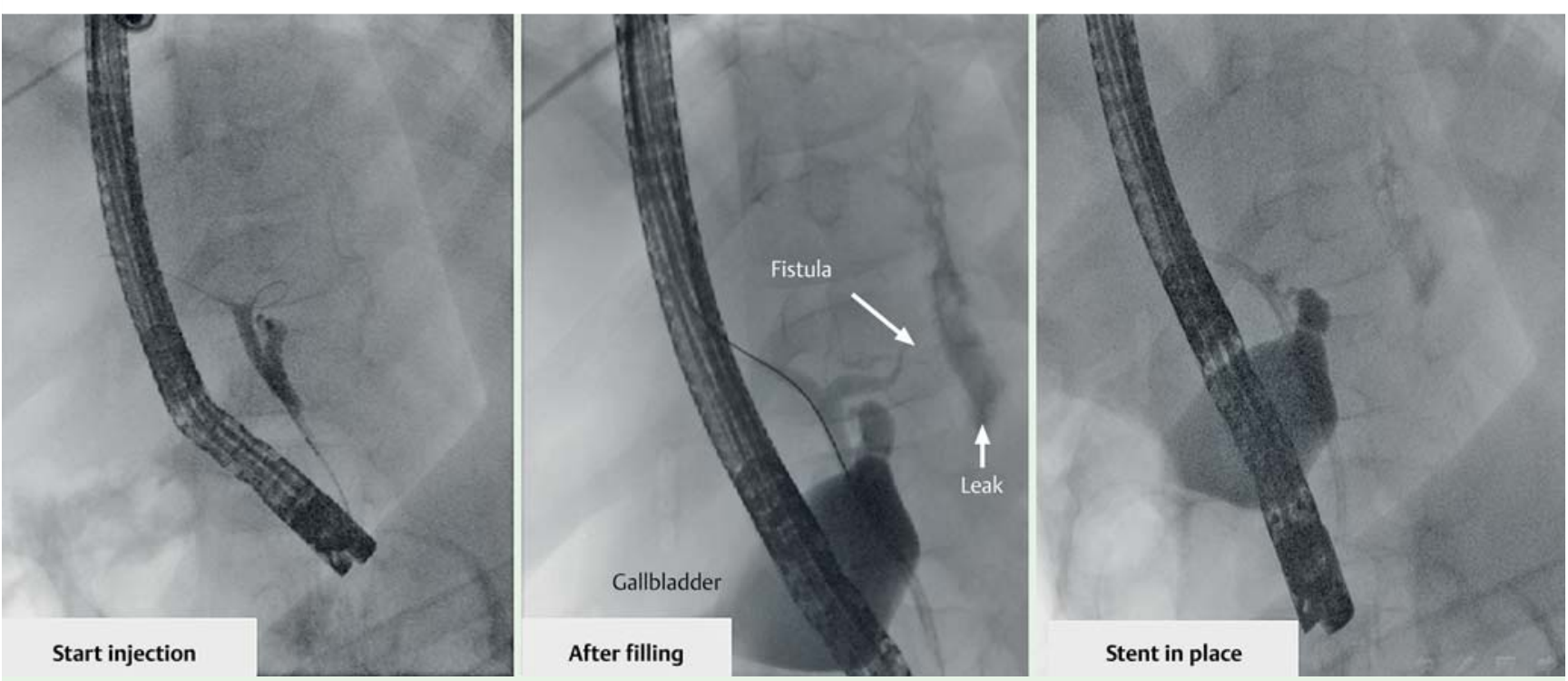

Fig. 1 Images during endoscopic retrograde cholangiopancreatography (ERCP) carried out on a 12-year-old boy with spinal, chest, and abdominal injuries who was noted to have bilious fluid draining from his chest tube (biliothorax) showing: $\mathbf{a}$ the appearance as contrast was being injected; $\mathbf{b}$ a bile leak from the subsegmental biliary pedicle and a biliopleural fistula; $\mathrm{c}$ a stent in situ.

About 20 months ago, an open letter was published in The Lancet calling for patients from the Syrian civil war to be treated [1]. Specifically, the letter said, "It is our professional, ethical, and moral duty to provide treatment and care to anyone in need".

The ongoing civil war in Syria has led to what is arguably one of the world's worst humanitarian crises. According to the Word Health Organization (WHO), 37\% of Syrian hospitals have been destroyed, 20\% are severely damaged, and more than $70 \%$ of Syria's medical professionals have fled the country $[1,2]$. Since the start of this conflict, approximately 700 Syrian warinjured, most of them civilian non-com- batants, have received medical treatment in Israel $[3,4]$.

Between December 2013 and October 2014, five Syrian civilians with multitrauma, including penetrating liver injuries complicated by bile leakage, were transferred to our medical center for further evaluation and treatment ( $\bullet$ Table 1 ).

All of the patients underwent diagnostic and therapeutic endoscopic retrograde cholangiopancreatography (ERCP). Bile leaks were diagnosed and treated endoscopically by biliary sphincterotomy either alone $(n=2)$ or combined with biliary stent insertion $(n=3)$. All of the external bile leaks (via percutaneous abdominal drains or chest tube), including that in a patient who had a biliopleural fistula ( $\bullet$ Fig. 1), resolved within 2-5 days of endoscopic intervention ( Table 1 ). The external drains were removed 2-3 days after the cessation of the bile leakage.

After a period of hospitalization ranging from 12 to 30 days, once their general condition had been stabilized, all of the patients were transferred back across the border with appropriate recommendations, including for removal of any stents that had been inserted. Unfortunately, we do not have long-term clinical or endoscopic follow-up.

Traumatic, non-iatrogenic biliary injuries, unlike iatrogenic injuries, are usually complex in nature and are frequently 
associated with multiorgan trauma and infection or sepsis.

A high risk surgical repair has been the conventional mode of therapy for posttraumatic bile leaks. Recent data has shown that ERCP is effective ( $>80 \%$ rates of healing) in managing bile leaks secondary to blunt or sharp traumatic liver injuries, using transpapillary endoscopic sphincterotomy, biliary stenting, or both. There is currently no consensus on which ERCP maneuver is superior [5].

As the war rages on, we will continue to provide medical care to anyone in need, just as was called upon for these patients.

Endoscopy_UCTN_Code_TTT_1AR_2AZ

Competing interests: None lyad Khamaysi, Alain Suissa,
Kamal Yassin, Ian M. Gralnek

Department of Gastroenterology and the Advanced Endoscopy Procedures Unit, Rambam Health Care Campus and Rappaport Faculty of Medicine, Technion-Israel Institute of Technology, Haifa, Israel

\section{References}

1 Brundtland GH, Glinka E, zur Hausen $\mathrm{H}$ et al. Open letter: let us treat patients in Syria. Lancet 2013; 382: 1019-1020

2 World Health Organization. Donor update, The Syrian Arab Republic, 9 April 2013. Available from: http://www.who.int/hac/ donorinfo/syrian_arab_republic_donorupdate9april2013.pdf. Accessed: 7 July 2015

3 Haaretz. Some 700 Syrians treated in Israeli hospitals since early 2013. Available from: http://www.haaretz.com/news/national/. premium-1.571622. Accessed: 7 July 2015

4 Zarka S, Barhoum M, Bader T et al. Israel's medical support to victims of the civil war in Syria. Isr Med Assoc J 2014; 16: 71 - 72

5 Lubezky N, Konikoff FM, Rosin D et al. Endoscopic sphincterotomy and temporary internal stenting for bile leaks following complex hepatic trauma. Br J Surg 2006; 93: 78 -81
Bibliography

DOI http://dx.doi.org/ 10.1055/s-0034-1392656

Endoscopy 2015; 47: E426-E427

(c) Georg Thieme Verlag KG

Stuttgart · New York

ISSN 0013-726X

\section{Corresponding author lyad Khamaysi, MD}

Department of Gastroenterology Rambam Health Care Campus

Rappaport Faculty of Medicine, Technion-Israel Institute of Technology

Haifa

Israel

Fax: +972-4-7773058

K_iyad@rambam.health.gov.il 